\title{
TEACHING AND LEARNING ENGLISH FOR VISUALLY IMPAIRED STUDENTS: AN ETHNOGRAPHIC CASE STUDY
}

\author{
Susanto \\ English Education Department, Bandar Lampung University, Indonesia \\ Centre for Studies in Linguistics, Bandar Lampung University, Indonesia \\ E-mail: susanto@ubl.ac.id \\ Deri Sis Nanda \\ English Education Department, Bandar Lampung University, Indonesia \\ Centre for Studies in Linguistics, Bandar Lampung University, Indonesia \\ E-mail: derisisnanda@ubl.ac.id
}

\begin{abstract}
APA Citation: Susanto, \& Nanda, D. S. (2018). Teaching and learning English for visually impaired students: An ethnographic case study. English Review: Journal of English Education 7(1), 83-92. doi: 10.25134/erjee.v7i1.1530.
\end{abstract}

Received: 23-08-2018

Accepted: 28-10-2018

Published: 01-12-2018

\begin{abstract}
In this article we report an ethnographic case study of observing the teaching and learning of English at a school for visually impaired students in Bandar Lampung, Indonesia. Data collection included student and teacher interviews. It also covered class observation and used a social constructivist framework of disability. The study revealed that the students received inadequate modifications of instruction in foreign language learning. However, the students used a variety of resources with the screen reader technology such as Non Visual Desktop Access (NVDA) and Job Access with Speech (JAWS). These findings suggest that visually impaired students actually can have unique ways of learning foreign language supported by the assistive technology. These abilities should be acknowledged to obtain the perspectives of students who receive disability specific education. Moreover, the study might provide a further facet to the research especially on the importance of learning strategies in special education.

Keywords: visual impairment; language education; learning strategy; special education.
\end{abstract}

\section{INTRODUCTION}

For the education system in Indonesia, learning English as a foreign language is required in building the global competitive skill focusing on knowledge and performance. Communication skill in English can bring more opportunities for the citizens in national and international labor market. Therefore, English is one of the subjects being taught in the schools in Indonesia. But, the English language course provided in the schools may not be designed properly for visually impaired students who have loss of vision.

Basically, visually impaired students pose difficulties in learning foreign language since human vision serves as a major stimulus for learning a language (Agesa, 2014; Arslantaş, 2017). Without vision, the students rely on the remaining senses of hearing and motor-kinesthetic feedback in learning. In teaching and learning the language, at least there are two basic barriers found in the classroom. The first is when the teaching materials are sight based lessons. The lessons consist of materials with visual format such as pictures. Then, the classroom may face difficulties to avoid pedagogical methods with sight based on visual perception.

The second is when the teachers are not aware of the specific needs of the students and the general implications of their visual impairments. They are not aware of how to behave towards the students. Also, they are not aware what the cognitive implications of the visual impairments for the students are. This may implicates slowing down the learning process in the classroom and the learning outcome is not maximum. In the 


\section{Susanto \& Deri Sis Nanda}

Teaching and learning English for visually impaired students: An ethnographic case study

study on observing the teaching and learning of English at a school for visually impaired students in Bandar Lampung, we underline those two basic barriers. We explore the students and teachers' experiences in the classrooms and the classroom interaction and pedagogy use.

By the constitution, the government of Indonesia is required to achieve not only the realization of justice and prosperity, but also the intelligence and welfare of the entire community, including the education for disabilities, e.g. visual impaired citizens. Therefore, as ruled in its national education system in the country, we could find special education intended for children with special needs. In the system, the special education is available for the levels of primary and secondary education. The system has the management patterns of Sekolah Luar Biasa (SLB) 'schools for special education' consisting of six types:

- SLB type A for visual impairment;

- SLB type B for hearing and speaking impairment;

- SLB type C for mental retardation;

- SLB type D for physical disability;

- SLB type E for the unsociable;

- SLB type G for multiple disabilities.

Categorizing the management patterns into the types of disabilities in Indonesia may result in discriminatory treatment for the students if the special curriculum is not well prepared and the teachers are not well trained to follow the future trends in inclusive education (Florian, 2008). Besides, in the special system within all types of the management patterns, the curriculum should not only anticipate the inclusive behaviours, conditions and processes comparing with the exclusive counterparts (Nugent, 2018), but also enhance the students' access to learning and social opportunities (Whitburn, 2014) especially in the context of developing countries (Birchler \& Michaelow, 2016; Masino \& Zarazúa, 2016).

In our ethnographic case study of observing the teaching and learning of English at a school for visually impaired students, we adopted a social constructivist framework. The framework approaches disability as a construction of social relations marginalizing those with bodies considered different from the normally functioning body. The social model differentiates between the physical limitation of impairment and the social construction of disability. As the matter of the physical limitation, the impairment involves a diminution of sight, hearing, mobility, and so on. While in the social construction, labelling disability could mean as a social process that turns an impairment into a negative by creating barriers to access. The impairment only becomes a disability when the ambient society creates environments with barriers (DePoy \& Gilson, 2011).

The social constructivist thinks that the impairment is not only seen as biological, objective, and static realities. But, it is contextual and linked to access in society (Thompson, 1997). Therefore, in the study, visual impairment is not a disabling physical limitation in itself, but a limitation placed on individuals by societal rules that define what a norm should be (Casper \& Talley, 2005). This gives rise to the following questions for the study:

- In the classroom, what strategies do the teacher and visual impaired students employ for teaching and learning English as a foreign language?

- What are the visually impaired students' perspectives on their experiences in learning English?

- What implications for the research and practice of special education do these findings have?

\section{METHOD}

To answer the questions, we conducted an ethnographic case study of English learning classes at a school for visually impaired students (SLB type C) in Lampung, a Southern part in Sumatra Island of Indonesia. The school was established in 1993 and now it has 33 students in total. The study is from April to June 2108. A total of three teachers (ages 28-45; 1 male, 2 females) and 15 students (ages 9-18; 11 
ENGLISH REVIEW: Journal of English Education Volume 7, Issue 1, December 2018
p-ISSN 2301-7554, e-ISSN 2541-3643

https://journal.uniku.ac.id/index.php/ERJEE

males, 4 females) were observed in 4 vision to total blindness.

classes. Students' vision varied from low

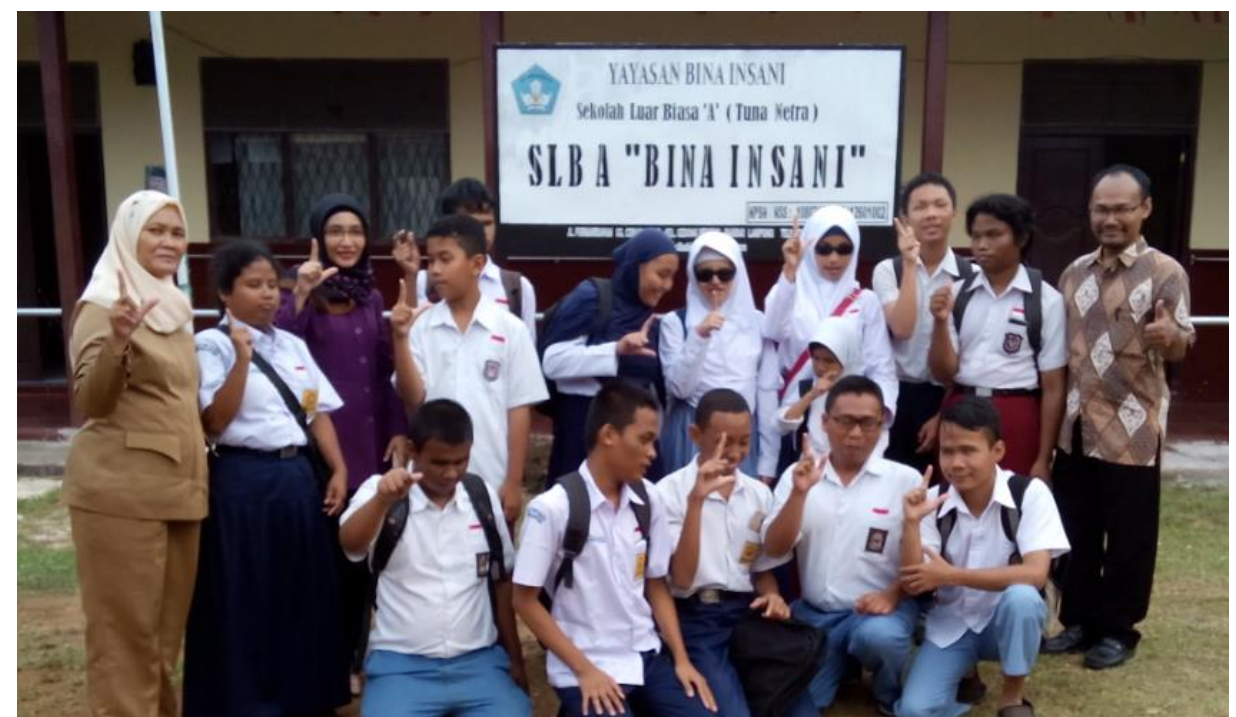

Figure 1. The students at the school for visually impaired students in Bandar Lampung, Indonesia.

The classroom observations were participant in nature (Reason, 1998; cf. Burns, 2018; Jones, Isham, \& Taylor, 2018). We participated in and occasionally taught some of the classes. The observations and interviews were audio and video-recorded. Field notes were also taken. The field notes were written in a notebook. The typed notes were taken on relevant information from viewing the video recordings of classes. In addition to the observations, interviews were conducted with selected participants including the teachers and students. The interviews were semi-structured. In the interviews, we allowed for unwritten followup questions and for the conversation to cover relevant areas. Questions for the students included their likes and dislikes of learning English and how it related to their impairments, and their communication experiences at the school. Questions for the teachers included their perception on the general abilities and desires of visually impaired students and their instruction in the classroom for the students. Table 1 shows the list of the predetermined questions asked to the students and the teachers.

Table 1. Predetermined questions asked to the students and the teachers.

\begin{tabular}{lll}
\hline Interview questions for students & - Can you tell me about learning English in your class? \\
& - What has been your most favorite part of your English class? \\
& - What has been your least favorite part of your English class? \\
& - Do you like learning English? Why? \\
\hline Interview questions for & - In what whink learning English is important? \\
teachers & different from sighted students? \\
& - What skill and knowledge do you want your students to gain in \\
& - Hour classes? \\
& - I noticed that you tried a particular pedagogical technique in class. \\
& Why did you do that? \\
& - Did you think it was successful?
\end{tabular}




\section{Susanto \& Deri Sis Nanda}

Teaching and learning English for visually impaired students: An ethnographic case study

We used the data from observations and interviews for themes that pertained to English learning as it relates to visual impairment. The themes were not determined a priori, but instead emerged from review of the data (Atkinson \& Hammersley, 1998; cf. Savage, 2013). To verify these themes, we used triangulation (Stake, 2005). The data was triangulated in two ways: investigator and methodological triangulations (Archibald, 2015; Denzin, 2006). For investigator triangulation, we independently analyzed the data, shared initial themes through memos and discussions, and then came to consensus on the emergent themes. For methodological triangulation, we used more than one method to gather data. The themes gathered from the data sources of teacher interviews, student interviews, and observation. We validate one another and provide different perspectives on the same theme.

\section{RESULTS AND DISCUSSION}

Two common themes emerged through the observations and interviews, i.e. firstly, students and teachers' experiences in the classrooms; secondly, the classroom interaction and pedagogy use.

\section{Students and teachers' experiences in the classrooms}

In interviews, students discussed their struggles in learning English. They described that some of their teachers were unknowledgeable to effectively teach them. They also thought that their teacher was lacking an interest to help them succeed because of the extra effort required to understand and provide for their needs. Student RZ said, "In English classroom, I had to do a lot of works to learn English but my teacher did not help me much in the classroom." While Student WD said, "My teacher called me to read difficult words and she did not explain the meaning of the words clearly." Student SH described her experiences in the classroom as frustrating because her teacher was insensitive to her needs during her learning English in the classroom. Her comments have called attention to an issue that, from her perspective, this lack of care affected badly her learning English in the classroom.

However, Students SR, AY and NK reported that in spite of having difficulties, they used a variety of resources with the help of Non Visual Desktop Access (NVDA) and Job Access with Speech (JAWS): "All materials are difficult, but we used NVDA and JAWS to help us". These students realized that learning materials in the classroom were not easy, but the screen reader technology can help them to get various materials from any resources for learning English. Figure 2 illustrates the use of screen reader technology in the classroom.

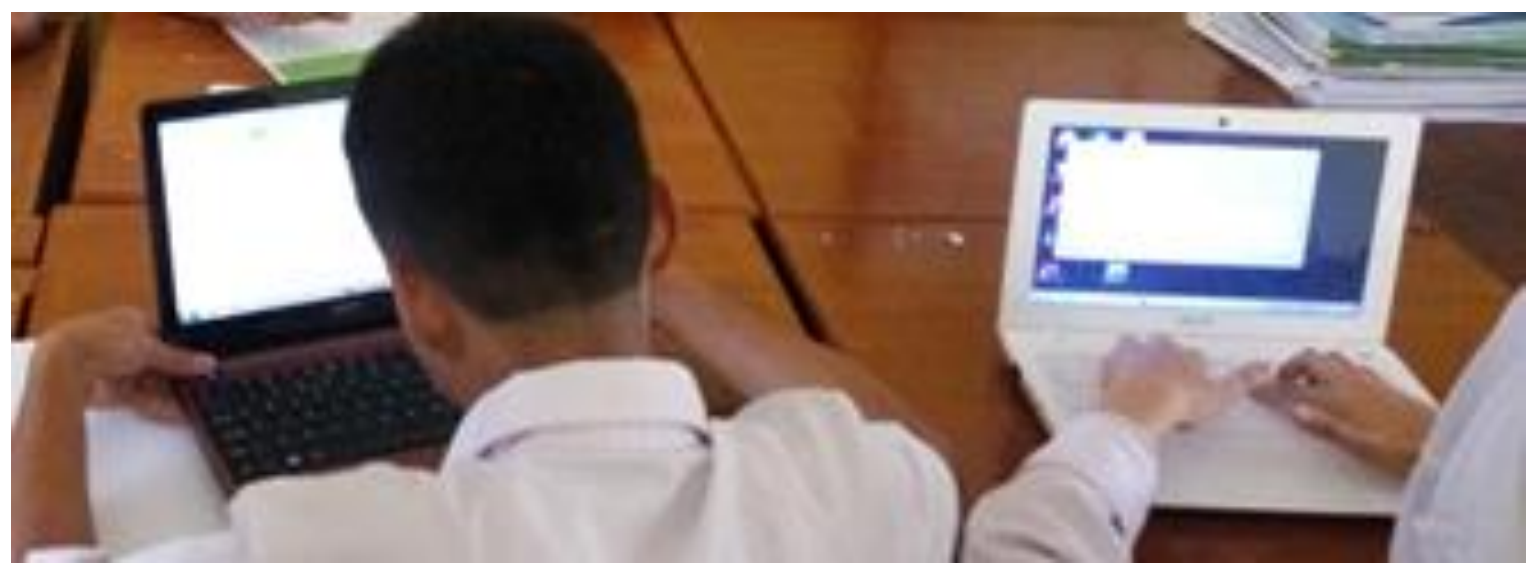

Figure 2. The use of screen reader technology by visual impaired students in the classroom. 
ENGLISH REVIEW: Journal of English Education Volume 7, Issue 1, December 2018

Meanwhile, Teacher EK emphasized the strategy of peer learning for studying vocabularies in place of reading Braille learning materials, "I don't use Braille materials for learning new vocabularies because the students would still end up memorizing the words." Further she commented that Braille takes a longer time to learn new words in the classroom. And, it creates an added step to the learning process that is not essential to learning the new words for the students.

In learning vocabularies, we find that some students did not like using Braille. Student AG said of his experiences with Braille, "I can learn some words with Braille. But, I thought it was confusing." $\mathrm{He}$ then added, "If I used it, I would still be memorizing the new words. So why continue with Braille if I can learn by my ears and I still have to memorize the words anyway?" Students GV, JW and DS found that Braille in learning new words was inconvenient. They felt that it was also time-
p-ISSN 2301-7554, e-ISSN 2541-3643

https://journal.uniku.ac.id/index.php/ERJEE

consuming for them. We noticed that in the classroom, the students learnt and memorized the new words and they preferred to give up using of Braille texts completely unless the teacher used the texts.

\section{The classroom interaction and pedagogy use}

When teaching and learning English, the teacher and students worked out various ways of communicating with one another. In the classroom, the students could not rely on visual cues. Therefore, communication through spoken language became important. For an example, Students NK and ST, often said repeatedly to each other during learning new words. And Teacher AC, often tried to help them to pronounce and communicate the new words among them and other students in the classroom intensively by tapping their shoulders. She believed that this act of tapping gesture can stimulate the students' active participation.

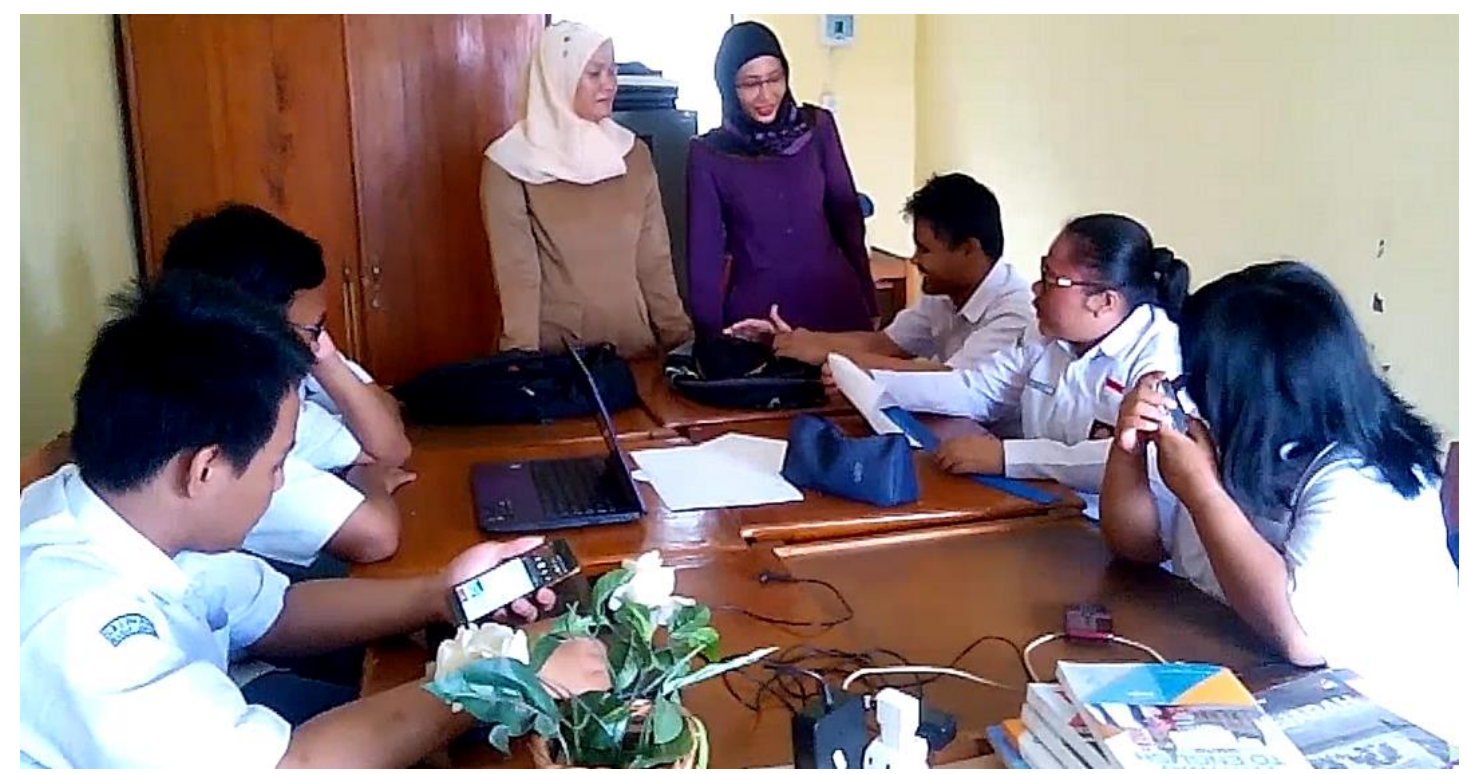

Figure 3. Classroom interaction with visual impaired students.

Teacher AC often avoided asking her students to match the vocabulary to the abstract meaning as always done by other teachers in the school. For her, it was more important to introduce the vocabulary with the concrete meaning connected with individual student's experience. For her class instruction, which typically consisted of four to six students, as a result, she would lead her students to learn the new words with background stories. The stories related 


\section{Susanto \& Deri Sis Nanda}

Teaching and learning English for visually impaired students: An ethnographic case study

to daily experiences can vary from one student to another student.

In another classroom, Teacher MT often had his students work in pairs to learn English vocabulary by using Braille. Unfortunately, his students NV and DT thought that learning the vocabulary in that way failed to help them learn and memorize many words. They also opined that it was not an effective method in the classroom.
The students place the blame of the ineffectiveness on the teacher. They believed their teacher neglected to modify instruction and material to be more interesting. The teacher's inadequate inclusion of instructional practices might result in the use of ineffective pedagogy and visual impaired students could perceive it as the barrier to access their learning outcome (Davis, 2002).

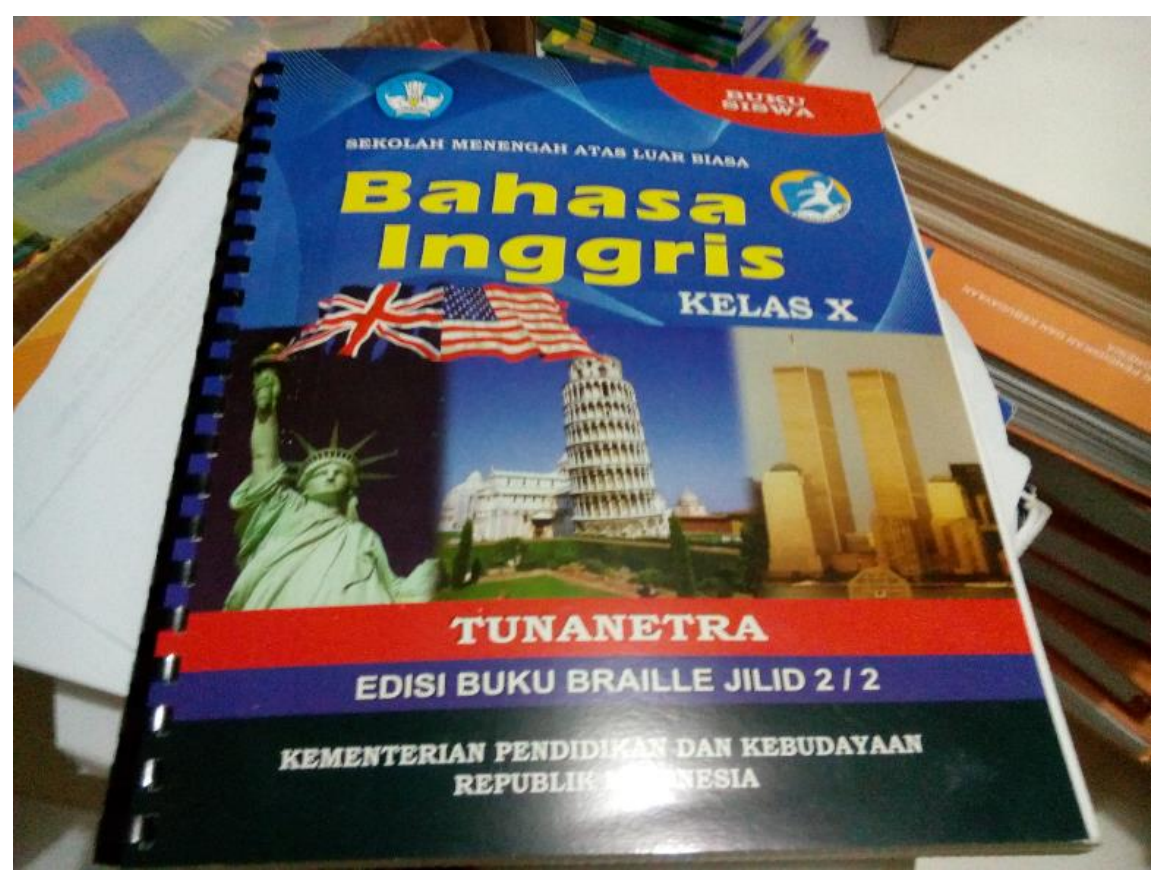

Figure 4. A Braille text book used in learning English for visual impaired students.

However, Students HD and SF enjoyed their experiences in learning English. In their class, Teacher MT used a role-play pedagogy. He asked his students' to play a simple drama by memorizing some dialogues. The students were allowed to improvise the dialogues. In the drama performance, the students got new words easily from the dialogues. Besides, a Braille text book was also used in the classroom (Fig. 4). In another classroom, which has only one student, i.e. Student ST, he also used the Braille text book. Moreover, learning process in the classroom was accompanied with the musical learning (Fig. 5). For him, English can be learnt through songs and he believed it was a good way for his student to learn a foreign language, at least from its melody and prosody. His belief is in line with the empirical studies showing that prosody is one of the critical elements in learning or acquiring language competence (Susanto, 2016; Weber, Braun \& Crocker, 2006). 


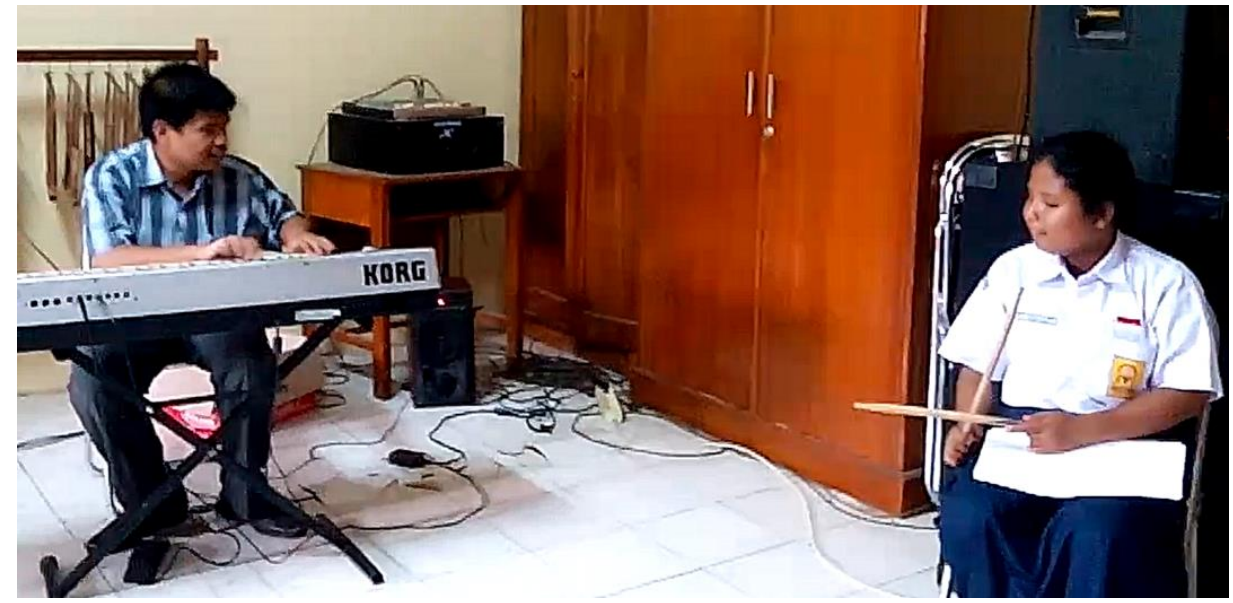

Figure 5. Musical learning for visual impaired students.

For Teachers EK, AC and MT, a Braille text book should not be ruled out as a resource in the school for visually impaired students. Although students can learn English without the aid of Braille text, it should be still considered as a necessary skill for teaching students with visual impairment. Therefore, they believed that it was compulsory to teach the students how to read and write Braille text (see Bozic \& McCall, 2007). Figure 6 illustrates a reglet, the tool for writing Braille text, used in the school for visual impaired students.

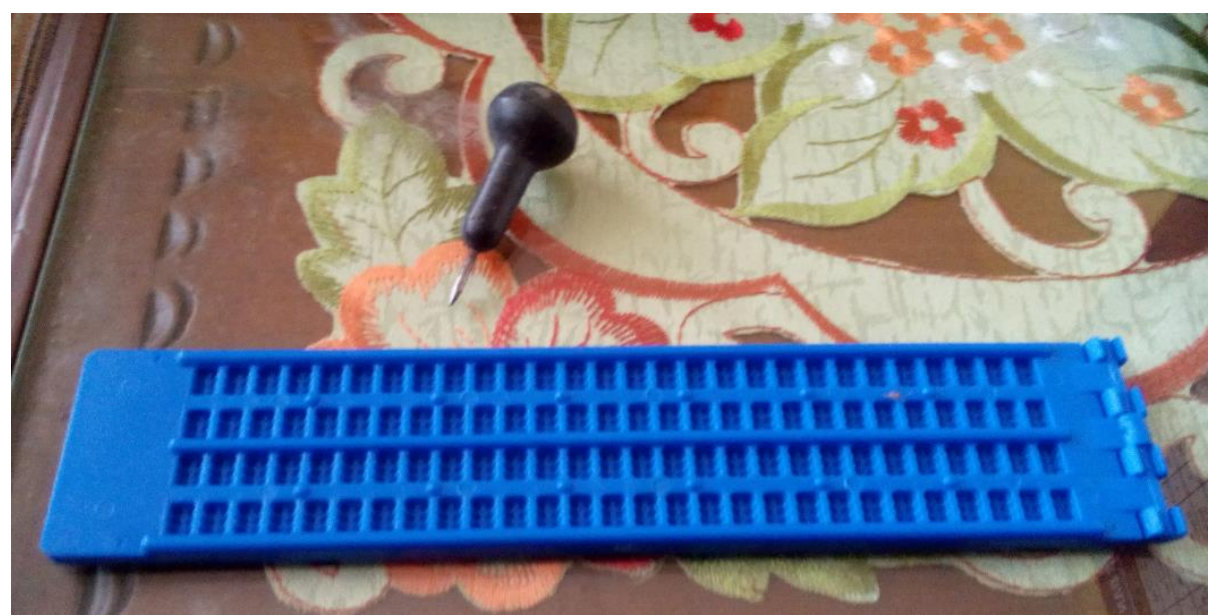

Figure 6. A reglet as the tool for writing Braille text used in the school.

From a social constructivist framework of disability (see also Bolt, 2005), the teachers' suggestions on the emphasis on using Braille text in learning English might create barriers to achieve fast language learning outcome (Danforth \& Gabel, 2006). This could ostracize the maximal use of listening for visual impaired students to learn English. Students with visual impairment could well prepared to learn a foreign language relying on their hearing sense. Thus, listening skill could be focused for visual impaired students.
In our observation, visually impaired students can have unique ways of learning foreign language, for examples by the assistive technology as experienced by Students SR, AY and NK (see Hersh \& Johnson, 2008); by role-play pedagogy as experienced by Students HD and SF; or by musical instrument as experienced by Student ST (see Goldstein, 2000). These abilities should be acknowledged to obtain the perspectives of students who receive disability specific education (Gabel, 2005) that can be incorporated with the perspective 


\section{Susanto \& Deri Sis Nanda}

Teaching and learning English for visually impaired students: An ethnographic case study

from the teachers or even from the parents (Jenks, 2005). The intersection of various pedagogies in learning language for visual impaired students with the ability of reading Braille texts might get beneficial. However, we suggest that the experiences of those with disabilities need to be more explored into the research within foreign language education to understand more about disability (Siebers, 2006).

\section{CONCLUSION}

In this article, we discussed our observation on the teaching and learning of English at a school for visually impaired students in Indonesia. It covered the students and teachers' experiences in the classrooms. It also included the discussion on the classroom interaction and pedagogy use. It was found that though the students received inadequate modifications of instruction in foreign language learning, they used a variety of resources with the screen reader technology such as Non Visual Desktop Access (NVDA) and Job Access with Speech (JAWS). Moreover, they could learn the language by role-play pedagogy and musical instrument as well. These findings suggest that visually impaired students actually can have unique ways of learning foreign language and these abilities should be acknowledged to obtain the perspectives of students who receive disability specific education. The study might provide a further facet to the research especially on the importance of learning strategies in special education.

\section{ACKNOWLEDGMENT}

The work described in this paper was supported by a research grant from the Indonesian Ministry of Research, Technology and Higher Education (PDUPT Scheme, 2018). The authors also thank the principal, teachers and students in the participating school.

\section{REFERENCES}

Agesa, L. (2014). Challenges faced by learners with visual impairments in inclusive setting in Trans-
Nzoia County. Journal of Education and Practice, 5(29), 185-192.

Archibald, M. M. (2015). Investigator triangulation: A collaborative strategy with potential for mixed methods research. Journal of Mixed Methods Research, 10(3), 228-250.

Arslantaş, T. K. (2017). Foreign language education of visually impaired individuals: A review of pervasive studies. IHEAD: Ihlara Journal of Educational Research, 2(2), 95-104.

Atkinson, P., \& Hammersley, M. (1998). Ethnography and participant observation. In N. K. Denzin \& Y. S. Lincoln (Eds.), Strategies of qualitative inquiry (pp. 110-136). Thousand Oaks, CA: Sage.

Birchler, K., \& Michaelow, K. (2016). Making aid work for education in developing countries: An analysis of aid effectiveness for primary education coverage and quality. International Journal of Educational Development, 48, 37-52.

Bolt, D. (2005). From blindness to visual impairment: Terminological typology and the social model of disability. Disability \& Society, 20, 539-552.

Bozic, N., \& McCall, S. (2007). Microcomputer software: Developing Braille reading skills. British Journal of Special Education, 20(2), 58.

Burns, D. (2018). Deepening and scaling participatory research with the poorest and most marginalised. European Journal of Operational Research, 268(3), 865-874.

Casper, M. J., \& Talley, H. L. (2005). Preface: Ethnography and disability studies. Journal of Contemporary Ethnography, 34(2), 115-120.

Danforth, D., \& Gabel, S. L. (2006). Vital questions facing disability studies in education. New York, NY: Peter Lang.

Davis, L. J. (2002). Bending over backwards: Disability, dismodernism, and other difficult positions. New York, NY: New York University Press.

Denzin, N. K. (2006). Sociological methods: A sourcebook. Piscataway, NJ: Transaction Publishers.

DePoy, E., \& Gilson, S. F. (2011). Studying disability: Multiple theories and responses. Thousand Oaks, CA: Sage.

Florian, L. (2008). Special or inclusive education: Future trends. British Journal of Special Education, 35(4), 202-208.

Gabel, S. L. (2005). Disability studies in education: Readings in theory and method. New York, NY: Peter Lang.

Goldstein, D. (2000). Music pedagogy for the blind. International Journal of Music Education, 35, 35-39.

Hersh, M. A., \& Johnson, M. A. (2008). Disability and assistive technology systems. In M. A. Hersh \& M. A. Johnson (Eds.), Assistive technology for visually impaired and blind people (pp. 1-50). London: Springer. 
ENGLISH REVIEW: Journal of English Education Volume 7, Issue 1, December 2018

Jenks, E. B. (2005). Parents' stories of raising children with visual impairments in a sighted world. Journal of Contemporary Ethnography, $34,143-169$.

Jones, C. B., Isham, L., \& Taylor, J. (2018). The complexities and contradictions in participatory research with vulnerable children and young people: A qualitative systematic review. Social Science \& Medicine, 215, 80-91.

Masino, S., \& Zarazúa, M. N. (2016). What works to improve the quality of student learning in developing countries? International Journal of Educational Development, 48, 53-65.

Nugent, M. (2018). Reframing inclusion: An exclusive-inclusive approach. British Journal of Special Education, 45(2), 141-156.

Reason, P. (1998). Three approaches to participatory inquiry. In N. K. Denzin \& Y. S. Lincoln (Eds.), Strategies of qualitative inquiry (pp. 324-338). Thousand Oaks, CA: Sage.

Savage, J. (2013). Participative observation: Standing in the shoes of others. Qualitative Health Research, 10(3), 324-339.
p-ISSN 2301-7554, e-ISSN 2541-3643 https://journal.uniku.ac.id/index.php/ERJEE

Siebers, T. (2006). Disability theory. Ann Arbor, MI: University of Michigan Press.

Stake, P. (2005). Qualitative case study. In N. K. Denzin \& Y. S. Lincoln (Eds.), The sage handbook of qualitative research (pp. 433-466). New York, NY: Sage.

Susanto (2016). A case study of prosodic phrasal grouping and intonational prominence in language acquisition. English Review: Journal of English Education, 4(2), 289-295.

Thompson, R. G. (1997). Extraordinary bodies: Figuring physical disability in American culture and literature. New York, NY: Columbia University Press.

Weber, A., Braun, B., \& Crocker, M. W. (2006). Finding referents in time: Eye-tracking evidence for the role of contrastive accents. Language and Speech, 49(3), 367-92.

Whitburn, B. (2014). Accessibility and autonomy preconditions to 'our' inclusion: A grounded theory study of the experiences of secondary students with vision impairment. Journal of Research in Special Educational Needs, 14(1), 3-15. 


\section{Susanto \& Deri Sis Nanda}

Teaching and learning English for visually impaired students: An ethnographic case study 